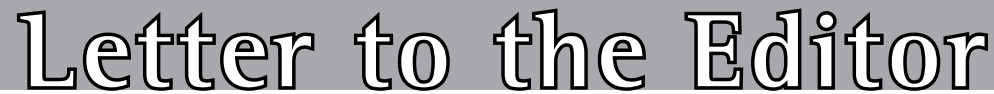

\section{Extracorporeal membrane oxygenation for postpneumonectomy ARDS}

\author{
Oxigenação extracorpórea por membrana no \\ tratamento da SARA pós-pneumonectomia

\begin{abstract}
Mauricio Guidi Saueressig, Patrícia Schwarz, Rosane Schlatter, Alexandre Heitor Moreschi, Orlando Carlos Belmonte Wender, Amarilio Vieira de Macedo-Neto
\end{abstract}

\section{To the Editor:}

Although ARDS is an uncommon complication of pneumonectomy, the associated mortality is high (ranging from 50\% to 100\%). ${ }^{(1)}$ Here, we report the case of a patient with postpneumonectomy ARDS that was satisfactorily managed by extracorporeal membrane oxygenation (ECMO). A 31-year-old White female patient diagnosed with cystic fibrosis 10 years prior presented with recurrent pneumonia secondary to bronchiectasis, predominantly in the left lung (Figure 1A). In the last two years,

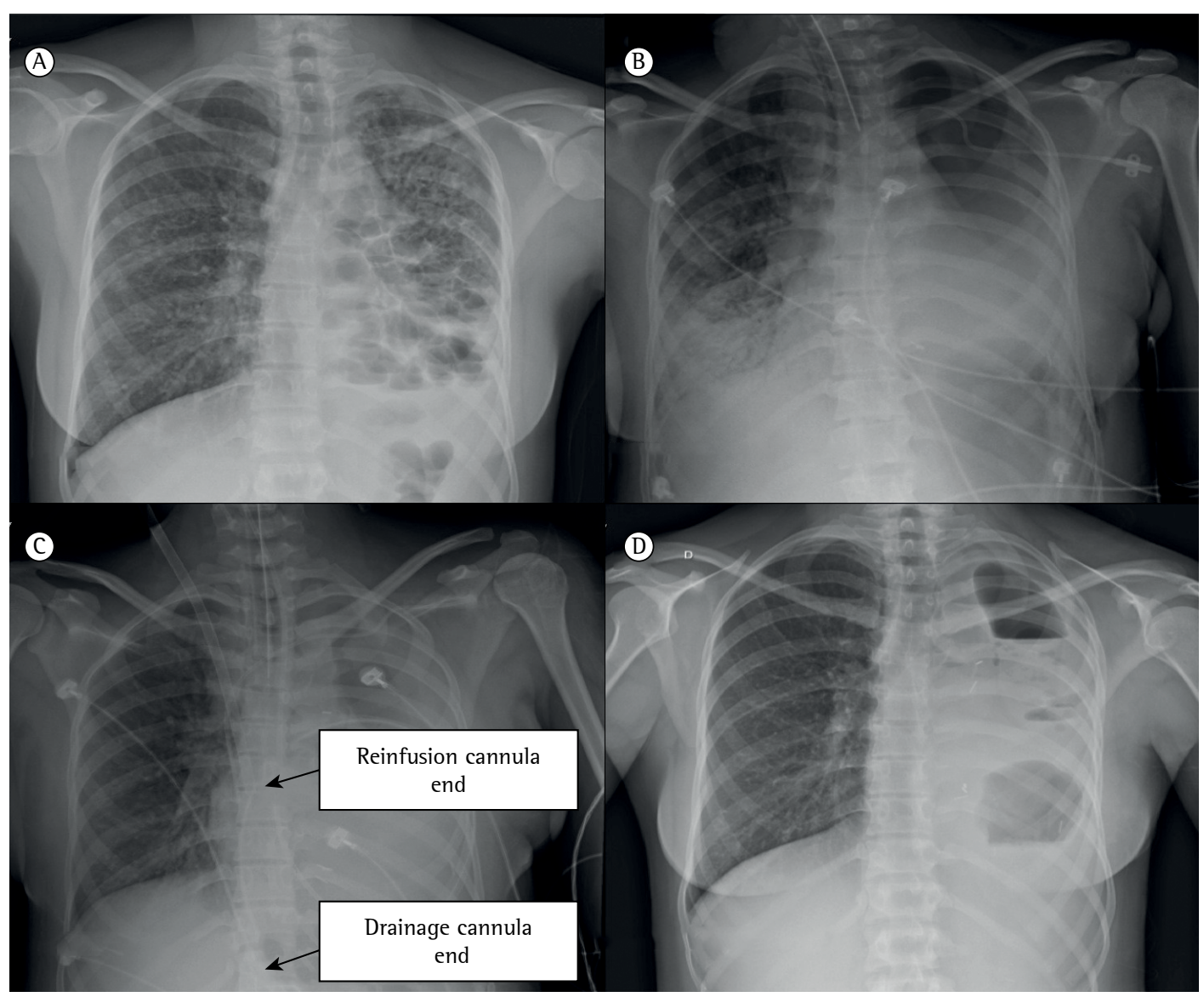

Figure 1 - Chest X-rays showing the progression of the patient. In A, chest X-ray taken before pneumonectomy, showing extensive bronchiectasis, reduced lung volume, and left pleural thickening. $\mathrm{ln} \mathrm{B}$, chest X-ray taken on postoperative day 3, showing extensive areas of consolidation on the right and the postpneumonectomy pleural space on the left. In C, chest X-ray taken on the day of weaning from extracorporeal membrane oxygenation (i.e., on postoperative day 8), showing resolution of the right-sided consolidation. Note the venous cannulae and their ends in the right atrium (for reinfusion) and in the intrahepatic portion of the inferior vena cava (for drainage). In D, chest X-ray taken three months after hospital discharge, showing nearly complete closure of the pneumonectomy cavity. 
Table 1 - Clinical status before initiation of and on the day of weaning from extracorporeal membrane oxygenation.

\begin{tabular}{|c|c|c|}
\hline Arterial blood gas results & Before ECMO & On the day of weaning from ECMO \\
\hline $\mathrm{pH}$ & 7 & 7.5 \\
\hline $\mathrm{PaO}_{2}, \mathrm{mmHg}$ & 108 & 136 \\
\hline $\mathrm{PaCO}_{2}, \mathrm{mmHg}$ & 115 & 57 \\
\hline $\mathrm{PaO}_{2} / \mathrm{FiO}_{2}$ & 107 & 388 \\
\hline \multicolumn{3}{|l|}{ Mechanical ventilation } \\
\hline PEEP, $\mathrm{cmH}_{2} \mathrm{O}$ & 8 & 6 \\
\hline $\mathrm{FiO}_{2}$ & 1.00 & 0.35 \\
\hline RR, breaths/min & 28 & 15 \\
\hline Tidal volume/ideal weight, $\mathrm{mL} / \mathrm{kg}$ & 4.4 & 5.8 \\
\hline Plateau pressure, $\mathrm{cmH}_{2} \mathrm{O}$ & 35 & 22 \\
\hline Peak inspiratory pressure, $\mathrm{cmH}_{2} \mathrm{O}$ & 45 & 26 \\
\hline Static lung compliance, $\mathrm{mL} / \mathrm{cmH}_{2} \mathrm{O}$ & 9 & 20 \\
\hline \multicolumn{3}{|l|}{ Hemodynamics } \\
\hline Norepinephrine, $\mu \mathrm{g} \cdot \mathrm{kg}^{-1} \cdot \mathrm{min}^{-1}$ & 0.16 & 0.00 \\
\hline Mean arterial pressure, $\mathrm{mmHg}$ & 66 & 90 \\
\hline $\mathrm{HR}, \mathrm{bpm}$ & 90 & 80 \\
\hline \multicolumn{3}{|l|}{ Serum test results } \\
\hline Lactate, $\mathrm{mmol} / \mathrm{L}$ & 0.4 & 0.9 \\
\hline Base excess, mmol/L & -3.5 & 17.0 \\
\hline C-reactive protein, $\mathrm{mg} / \mathrm{L}$ & 231 & 17 \\
\hline Hemoglobin, g/dL & 10 & 9 \\
\hline \multicolumn{3}{|c|}{ Sedation/neuromuscular blockade/scores } \\
\hline Midazolam, $\mathrm{mg} \cdot \mathrm{kg}^{-1} \cdot \mathrm{h}^{-1}$ & 0.2 & 0 \\
\hline Fentanyl, $\mu \mathrm{g} \cdot \mathrm{kg}^{-1} \cdot \mathrm{h}^{-1}$ & 4 & 2 \\
\hline Atracurium, $\mathrm{mg} \cdot \mathrm{kg}^{-1} \cdot \mathrm{h}^{-1}$ & 0.6 & 0.0 \\
\hline SOFA score & 14 & 7 \\
\hline Murray score & 3.0 & 1.2 \\
\hline
\end{tabular}

ECMO: extracorporeal membrane oxygenation; PEEP: positive end-expiratory pressure; and SOFA: Sequential Organ Failure Assessment.

despite continuous use of antibiotics (500 $\mathrm{mg}$ of azithromycin p.o. three times a week), the patient had had seven respiratory infections, as well as purulent sputum between episodes. Therefore, a decision was made to perform a left pneumonectomy. The postoperative course was satisfactory. However, on postoperative day 2 , the patient showed dyspnea, cough with purulent sputum, tachypnea, left-sided chest pain, inspiratory rales in the lower lung fields, and hypoxemia $\left(\mathrm{SaO}_{2}<70 \%\right)$. Initial management with noninvasive ventilation was ineffective, the patient being therefore placed on mechanical ventilation on postoperative day 3 (Figure 1B). After $17 \mathrm{~h}$ of mechanical ventilation, she still had ARDS, hypoxemia, and a $\mathrm{pH}<7.2$, despite alveolar recruitment maneuvers, attempts to reduce tidal volume, oxygen insufflation into the trachea, and neuromuscular blockade (Table 1). Therefore, a decision was made to place her on venovenous ECMO (a Revolution ${ }^{\mathrm{TM}}$ centrifugal pump and an EOS
ECMO adult membrane oxygenator; Sorin, Milan, 1taly). Percutaneous cannulation of the femoral and jugular veins was performed by the Seldinger technique, a 19-F arterial cannula being inserted into the right internal jugular vein for reinfusion and a 29-F venous cannula being inserted into the right femoral vein for drainage (Maquet, Rastatt, Germany). Venipuncture and cannulation of the jugular and femoral veins were performed under ultrasound guidance at the bedside. Continuous i.v. infusion of unfractionated heparin was used in order to achieve an activated clotting time of 160-200 s. Initially, ECMO blood flow was 60 $\mathrm{mL} \cdot \mathrm{kg}^{-1} \cdot \mathrm{min}^{-1}$, being subsequently adjusted to maintain a $\mathrm{PaO}_{2}>50 \mathrm{mmHg}$, whereas gas flow (sweep gas) was titrated to maintain a $\mathrm{pH} \geq$ 7.3. The temperature of the patient remained at $35.5-36.5^{\circ} \mathrm{C}$. Lung rest was achieved by pressurecontrolled ventilation at protective ventilator settings (i.e., a plateau pressure $\leq 25 \mathrm{cmH}_{2} \mathrm{O}$, a positive 
end-expiratory pressure of $5-15 \mathrm{cmH}_{2} \mathrm{O}$, and an $\mathrm{FiO}_{2}$ $\leq 0.4$ ). The patient showed progressive radiological improvement (Figure 1C), as well as progressive improvement in arterial blood gas parameters and lung compliance, meeting the criteria for weaning on ECMO day 5 (Table 1). Three hours later, she was successfully extubated. The patient was discharged on postadmission day 21 . There were no hemorrhagic or thromboembolic complications of ECMO. The total cost of ECMO, in Brazilian reals (R\$), was $33,470.16, R \$ 26,315.00$ having been spent on the ECMO circuit plus medical supplies (including cannulae), $R \$ 5,594.93$ having been spent on the ICU stay, and R\$1,560.23 having been spent on diagnostic tests. However, the amount paid by the Sistema Único de Saúde (SUS, Brazilian Unified Health Care System) via the Authorized Hospital Admissions system was R \$ 5,917.88.

The incidence of ARDS after left pneumonectomy is approximately $4 \% .{ }^{(2)}$ Possible triggers include reduced lymphatic drainage and single-lung ventilation with hyperoxia. ${ }^{(3)}$ Supportive care consists of mechanical ventilation; however, in cases of refractory hypoxemia, rescue therapies include prone positioning ${ }^{(4)}$ and ECMO. ${ }^{(5)}$

An invasive method, ECMO corrects severe hypoxemia and hypercapnia $(\mathrm{pH} \leq 7.2)$ and reduces $\mathrm{FiO}_{2}(<0.5)$ and plateau pressure to safer levels, allowing the lung to rest in cases of ARDS. ${ }^{(6,7)}$ Despite a $\mathrm{PaO}_{2} / \mathrm{FiO}_{2}$ ratio $>100 \mathrm{mmHg}$, early ECMO was recommended because of the presence of an $\mathrm{FiO}_{2}>0.8$, a plateau pressure $>30 \mathrm{cmH}_{2} \mathrm{O}$, a $\mathrm{pH}<7.2$, and a $\mathrm{PaCO}_{2}>100 \mathrm{mmHg}$ in our patient. In addition, her Sequential Organ Failure Assessment score was 14, indicating the absence of multiorgan involvement and showing that the ECMO team at the Porto Alegre Hospital de Clinicas, located in the city of Porto Alegre, Brazil, abides by the policy that ARDS patients who are not at risk of imminent death should be recognized as candidates for ECMO. This approach has been advocated by other ECMO teams in Brazil. ${ }^{(8,9)}$

A novel technique, ECMO is currently not covered by the SUS; the reimbursement that our hospital received from the SUS covered less than $20 \%$ of the actual costs. Therefore, there is a need for an economic evaluation of ECMO in Brazil in order to inform the decision of whether ECMO should be included in the range of procedures covered by the SUS.
On the basis of the case reported here, we recommend early rescue therapy with venovenous ECMO for patients with postpneumonectomy ARDS accompanied by hypoxemia and respiratory acidosis refractory to mechanical ventilation, provided that the medical team has sufficient experience with the procedure, which is complex and costly.

Maurício Guidi Saueressig Adjunct Professor, Department of Surgery, Porto Alegre Hospital de Clínicas, Federal University of Rio Grande do Sul School of Medicine, Porto Alegre, Brazil

\section{Patricia Schwarz}

Intensivist, Department of Intensive Care, Porto Alegre Hospital de Clínicas, Federal University of Rio Grande do Sul School of Medicine, Porto Alegre, Brazil

Rosane Schlatter

Doctoral Student, Graduate Program in Cardiology and Cardiovascular Sciences, Federal University of Rio Grande do Sul School of Medicine, Porto Alegre, Brazil

Alexandre Heitor Moreschi Physician, Department of Thoracic Surgery, Porto Alegre Hospital de Clínicas, Federal University of Rio Grande do Sul School of Medicine, Porto Alegre, Brazil

\section{Orlando Carlos Belmonte Wender Adjunct Professor, Department of Surgery, Porto Alegre Hospital de Clínicas, Federal University of Rio Grande do Sul School of Medicine, Porto Alegre, Brazil}

Amarilio Vieira de Macedo Neto Adjunct Professor, Department of Surgery, Porto Alegre Hospital de Clínicas, Federal University of Rio Grande do Sul School of Medicine, Porto Alegre, Brazil 


\section{References}

1. Dulu A, Pastores SM, Park B, Riedel E, Rusch V, Halpern NA. Prevalence and mortality of acute lung injury and ARDS after lung resection. Chest. 2006;130(1): 73-78.

2. Waller DA, Gebitekin C, Saunders NR, Walker DR. Noncardiogenic pulmonary edema complicating lung resection. Ann Thorac Surg. 1993;55(1):140-3. http:// dx.doi.org/10.1016/0003-4975(93)90490-9

3. Hyde BR, Woodside KJ. Postoperative acute respiratory distress syndrome development in the thoracic surgery patient. Semin Thorac Cardiovasc Surg. 2006;18(1):2834. http://dx.doi.org/10.1053/j.semtcvs.2005.12.002

4. Guérin C, Reignier J, Richard JC, Beuret P, Gacouin A, Boulain $\mathrm{T}$, et al. Prone positioning in severe acute respiratory distress syndrome. $\mathrm{N}$ Engl J Med. 2013;368(23):2159-68. http://dx.doi.org/10.1056/ NEJMoa 1214103

5. Peek GJ, Mugford M, Tiruvoipati R, Wilson A, Allen E, Thalanany MM, et al. Efficacy and economic assessment of conventional ventilatory support versus extracorporeal membrane oxygenation for severe adult respiratory failure (CESAR): a multicentre randomised controlled trial. Lancet. 2009;374(9698):1351-63. http://dx.doi. org/10.1016/S0140-6736(09)61069-2

6. Brower RG, Ware LB, Berthiaume Y, Matthay MA. Treatment of ARDS. Chest. 2001;120(4):1347-67. http://dx.doi. org/10.1378/chest.120.4.1347

7. Terragni PP, Rosboch G, Tealdi A, Corno E, Menaldo E, Davini 0, et al. Tidal hyperinflation during low tidal volume ventilation in acute respiratory distress syndrome. Am J Respir Crit Care Med. 2007;175(2):160-6. http:// dx.doi.org/10.1164/rccm.200607-9150C

8. Park M, Azevedo LC, Mendes PV, Carvalho CR, Amato MB, Schettino GP, et al. First-year experience of a Brazilian tertiary medical center in supporting severely ill patients using extracorporeal membrane oxygenation. Clinics (Sao Paulo). 2012;67(10):1157-63. http://dx.doi.org/10.6061/ clinics/2012(10)07

9. Azevedo LC, Park M, Costa EL, Santos EV, Hirota A, Taniguchi LU, et al. Extracorporeal membrane oxygenation in severe hypoxemia: time for reappraisal? J Bras Pneumol. 2012;38(1):7-12. 